\title{
Financial Performance and Income Diversity: Does Ownership Matter? Evidence from Vietnamese Commercial Banks
}

\author{
Tin $\mathrm{H} . \mathrm{Ho}^{1,2}$ \\ ${ }^{1}$ Institute for Development \& Research in Banking Technology, University of Economics and Law, Ho Chi \\ Minh City, Vietnam \\ ${ }^{2}$ Vietnam National University, Ho Chi Minh City, Vietnam \\ Correspondence: Tin H. Ho, Institute for Development \& Research in Banking Technology, University of \\ Economics and Law, Vietnam National University, Ho Chi Minh City - Quarter 3, Linh Xuan Ward, Thu Duc \\ District, Ho Chi Minh City, Vietnam. Tel: 84-961-199-716. E-mail: tinhh@uel.edu.vn
}

Received: June 4, 2020

Accepted: June 27, 2020

Online Published: July 10, 2020

doi:10.5539/ijef.v12n8p77

URL: https://doi.org/10.5539/ijef.v12n8p77

\begin{abstract}
In the context of the sharp development of the Vietnamese stock market in recent years, financial performance of listed firms is drawing the attention of investors, particularly in banking industry. Moreover, the harmony of income diversity or reducing the relying on traditional activities of commercial banks is thriving in the world and strongly influence on Vietnam's banking, especially when the outbreak of COVID-19 worldwide may result in the freeze of real estate market, which leads to devaluate collaterals as well as the risk of non-performing loans, so-called "credit shocks". This paper, therefore, examines the impacts of income diversity on financial performance of Vietnamese commercial banks in the period from 2007 to 2019. To conduct this study, annual data are collected of 26 commercial banks, listed in Ho Chi Minh Stock Exchange (HOSE), Ha Noi Stock Exchange (HNX), UPCoM and OTC. The research develops an exploratory model reflecting financial performance of the banks in relation to their income diversity and analyzes data using panel regressions. The results show that there is no relationship between financial performance and income diversity due to its low proportion in total operating income. However, the state ownership makes stronger this relationship despite the small impacts. The findings are expected to add the gap in the existing literature, lacking of investigating the impacts of market power on bank income diversity, and the moderating role of state ownership in this relation in Vietnamese banking sector, which is ignored or opposite in most recent studies. Thereby, the paper also gives some useful implications for investors, bank managers as well as policy makers to catch up the market fluctuations.
\end{abstract}

Keywords: financial performance, income diversity, ownership, Vietnamese joint stock commercial banks

\section{Introduction}

In the modern era, stock investments have become one of the various investment options that are quite attractive to both foreign and local investors. The motivation of investors to make investment decisions is to maximize the level of profit. For investors or owners of capital, the level of profits or returns is certainly an important indicator in an effort to increase prosperity. Returns are defined as profits obtained by companies, individuals, and institution from the results of their investment policies or as profits obtained through share ownership over a certain period of time (Juniarta \& Purbawangsa, 2020). In order to make investment and earn returns, stock market has been born and is considered to be a critical part of the economic system in which ownership of a firm can be bought or sold (Myers, 2001) through issuing and trading securities (Mishkin \& Eakins, 2010). In short, stock market provides a platform for firms to raise funds (Gatua, 2013). Due to some vital roles, stock market is seemed to have acted as a barometer of the financial health of listed firms for a long time (Mc Gregor \& Mc Gregor, 1989).

In order to drive the attention of investors in a recently competitive environment, listed companies have to develop suitable business strategies, managerial countermeasures and investor relation policies. These are represented and clarified by firm's performance. Every performance has many implications, especially financial performance which affects the finance field of a business. This raises a concern that what the role of financial performance is in drawing the attention of investors and how they can do that, particularly in banking industry where operations relate to a very sensitive area - currency, needing to be considered with a high caution and 
carefulness. Moreover, after global financial crisis in 2008, the world banking system is in the line with financial deregulation, liberalization, and international economic integration, facing major changes from increase competition between domestic banks and foreign banks to restructuring the financial system by the central bank's policies of each country. The investors, hence, not only care about the banks' financial performance, but also want to know their operations or in particular, how the banks can diversify their income structure in response to market uncertainties when the credit activities are not stable and may contain many risks.

The role of diversification on performance, therefore, continues to be heavily investigated amid the conflicting empirical and theoretical disagreement documented in economics and finance literature. Some resource base view theory and internal market hypothesis argued that diversification might induce firm's operating efficiency, broaden debt capacity and lower tax (Berger \& Ofek, 1995; Lu \& Beamish, 2004; Zahavi \& Lavie, 2013). Though there are also potential costs in diversification strategy, diversified firms may have increased discretionary resources to undertake value-decreasing investments, cross-subsidies that allow poor segments to drain resources from better-performing segments, and misalignment of incentives between central and divisional managers (Fauver et al., 2003; Lee et al., 2014). Thus, investigating the diversification strategy effect on bank's performance is always interesting. Most of those studies, however, are either based on developed countries (e.g. Europe and US) or within non-financial firms. For example, De Jonghe (2010) and Fiordelisi et al. (2011) both found that European bank's might face more risk when they diversify their income sources but it is beneficial. Meslier et al. (2014) also stated that when the banks reduced their relies on traditional activities, they would increase their profitability as well as their risk-adjusted profits. Contrarily, DeYoung and Roland (2001) address 3 mains reasons why non-interest income may harm bank's income. On the other hand, little is known about the income diversity effect on banking industry, especially within the context of developing countries. It's believed that the main factors that drives banks to diversify their income may be similar in both developed and emerging markets, but institutional characteristics could possibly lead to different diversification effects, which may give different and interesting perspective than in developed markets. That is the biggest reason for this paper is to be conducted.

The Vietnamese stock exchange, developed in 2000, is an emerging market, but plays an important role in capital formation and raising economic growth through buying and selling securities. It has been operating with two official trading centers, namely HOSE (Ho Chi Minh Stock Exchange) and HNX (Hanoi Stock Exchange) since 2005, and two unofficial trading centers as UPCoM and OTC. These stock exchanges are considered to be one of the efficient channels for mobilizing funds of Vietnamese joint stock companies and commercial banks as well. Vietnam is a developing country, and this could offer different snapshot in term of different institutional setting. Comparatively, banking industry in developing countries tends to have less efficient operation activity, and less developed external market forcing them to impose diversification strategies (Rayenda et al., 2018). In spite of emerging market, the Vietnamese banking system is growing day by day. Overall, it has social policy banks, one-member limited liability commercial banks owned by the state (Agribank, Ocean bank, Global Petro bank, and Construction bank) $100 \%$ foreign-owned banks, branches of foreign commercial banks (HSBC, Shinhan, MUFG, ...), joint venture banks (VRB, IVB) and joint stock commercial banks which accounts for the majority and is the main scope of this study.

Until now, in Vietnam there is not much noticed enough on financial performance and income diversity in Vietnamese banking industry due to its special business areas. In the modern economy, Vietnamese commercial banks act as intermediaries, carrying out mobilizing idle funds through deposits, current accounts or savings and providing these funds for those who needs by loans in order to earn interest income. These are so-called traditional activities and the main roles of any commercial banks. This is the reason why loans to customers and deposits from customers often make up a highest proportion in the bank's total assets and liabilities, relatively; investment and financing performance, hence, are accidentally ignored when studying as well as income from non-traditional activities. Harmony with the global trend, the Vietnamese Government has also realized the lending practices in the country tend to rely on collaterals rather than careful credit assessments, leading to excessive risk taking since 2008; therefore, the Project on Restructuring the Vietnamese Credit Institution System in the period from 2011 to 2015, was approved by the Prime Minister through Decision No. 254/QĐ-TTg dated on March $1^{\text {st }}$ 2012, emphasizes: "Shifting the business model of commercial banks in the direction of reducing the dependence on credit activities and increasing income from non-credit services step by step". Follow this policy, by the end of 2019, Vietnam's banking sector recorded a credit growth of 13.5 percent year-on-year, the lowest since 2014 (see more in Figure 1). This, thereby, raises a question: "Will the shift toward non-interest income affect the banks' financial performance?". The diversification strategies, in addition, could be considered as kill two birds with one stone under the current situation when the world is facing the COVID-19 
pandemic. On the one hand, income diversity helps the banks, of course, diversify their income structure, leading to increase net profits. On the other hand, banks can reduce the relying on credit activities, which means declining the possibility of facing credit risks. Particularly, the massive economic shock worldwide, resulting from the onset of this pandemic, is placing unprecedented pressures on the whole economy of every country, including Vietnam. This has also made planning for the next normal increasingly complex for each industry. However, the banking industry, which usually plays a role as an intermediary for transferring capitals from the lenders to the borrowers, now undertakes more responsibility as a pioneer of supporting companies in other industries and communities by launching some credit support packages as the requests of the State Bank of Vietnam (SBV) as well as the Governor, presented in Circular 01/2020/TT-NHNN. Nevertheless, they are considered to be a double-edge sword. The supports of restructuring loans, reducing lending rates, extending repayment period, removing overdue penalty interest rates, etc. (applied in Vietcombank, Vietinbank, BIDV, Eximbank, TPbank, ...) make Vietnamese commercial banks be in danger of increasing non-performing loans (NPLs), especially when the severe impacts of COVID-19 on the real estate market, which is the main collaterals for most bank loans.

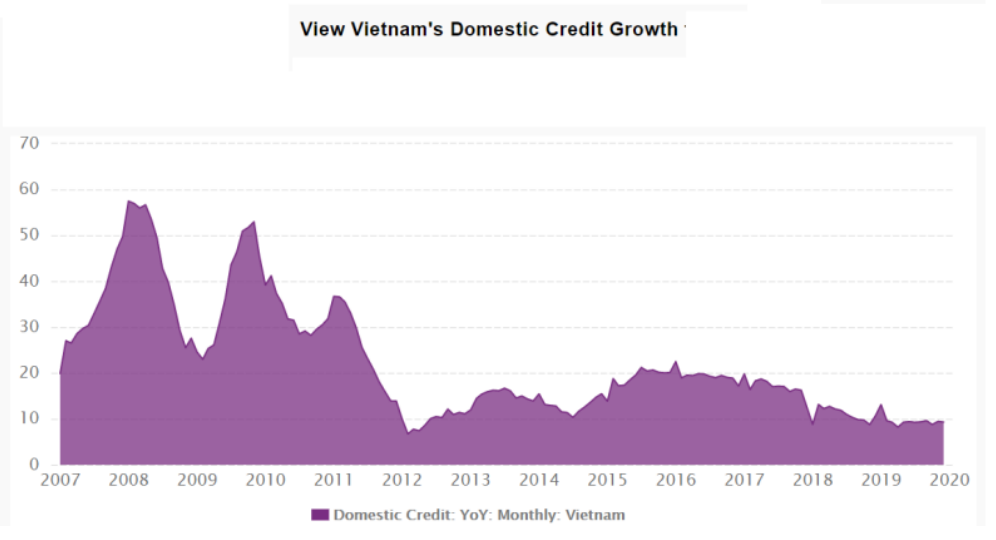

Figure 1. Vietnam's domestic credit growth from 2007 to 2019

Source: www.ceicdata.com.

This paper, as a result, aims to contribute the existing literature by figuring out the actual impacts of income diversity on financial performance of 26 Vietnamese commercial banks, listed in the 4 stock exchanges HOSE, HNX, UPCoM and OTC from 2007 to 2019. Out of the box, this paper also takes into account the role of state ownership in these impacts because of the general control of the State Bank of Vietnam (SBV) on the banking system as well as the regulatory role of the state-owned commercial banks, which creates a unique environment compared to other developing countries.

So as to reach the main goals, this study reviews theoretical frameworks to develop measuring criteria for financial performance and income diversity. Additionally, this paper also takes a look at previous researches to find out the current status (or the gap) of the studies. Then, collected data is analyzed by some methods for panel data analysis. At the end, this paper gives some discussion related to the findings and some useful recommendations for investors, bank managers, and policy makers. Following this introductory section, the other sections of the paper are arranged into four parts as literature review, data sources and methodology, the empirical results, conclusions and suggestions.

\section{Literature review}

\subsection{Key Concepts}

\subsubsection{Financial Performance}

Investors often review company's annual financial accounts and reports to evaluate the historical and current financial performance so as to predict the future financial performance of a company in order to keep track of its value created year-on-year. At the end of the fiscal years, the results of financial management in corporations with other business activities are reflected on firms' financial statements and measured by financial indicators (Ngo \& Dang, 2016). It is pointed out that the company's financial statements should have valuable information (about its performance and fiscal health) that can be used as a decision making reliable and useful. Complete financial 
statements usually consist of 5 components, namely (1) balance sheet, (2) income statement, (3) statement of owner equity, (4) statement of cash flows, and (5) notes to the financial statements.

This is done to see the extent of the financial statements could reflect the relationship between risk and returns that correspond to the individual preferences. The financial statements could cause a market reaction (the behavior of investors and other market participants in the transaction either buy or sell stocks) when it contains accurate information. In most recent study, financial performance is measured in terms of profitability, liquidity, solvency, financial efficiency and repayment capacity. Particularly, it is often is proxied by some financial ratios as net profit margin, earning per share (EPS), return on equity (ROE), return on asset (ROA), and quick ratio (Anwaar, 2016; Felicia \& Akin, 2018).

\subsubsection{Income Diversity}

Banks' revenues come from two primary sources, the one is so called traditional activities, generating interest income, and the other is non-traditional activities, generating non-interest income. Traditional activities of a bank are defined as the financing of loans with deposits, showing the intermediary role of the bank as transferring funds from depositors to borrowers (Gorton \& Rosen, 1995; Rogers \& Sinkey, 1999).

On the other hand, the most common feature of non-traditional activities is producing fee-based, trading-based, and investment-based income. Income diversity in banking sector refer to increasing share of non-interest income within net operating income and reducing the dependence on interest income of a bank (Hafidiyah \& Trinugroho, 2016).

In the banking and finance literature, income diversity is, in general, to help reduces the risk of loan failure. This strategy leads to greater diversification of income sources, which might help banks to reduce risks and stabilize profits. According to Rayenda et al. (2018), banks could reach disintermediation in their income by expanding non-interest product activities as brokerage, trading securities, investment banking and other financial activities.

\subsubsection{Ownership Structure and State Ownership}

Ownership structure can explain the activities managers and owners do in a firm. Jesen and Meckling (1976) also agreed that organizational form influenced operating behaviors, as it defined the nature of residual claims, which was also the motivation of the firm's owners. According to the prior theoretical and empirical literature, the agency problems and risk-taking behavior varies across firms due to the nature of shareholders, especially controlling shareholders, who enjoy significant shared control benefits (Barry et al., 2011; Lassoued et al., 2016). There are several ways to classified ownership types in banking industry, but the most common classification is based on the ownership structure characteristics or types of shareholders as state (or public) ownership, domestic privately ownership and foreign ownership. For instance, banks were considered to be state-owned if state shareholders controlled more than $50 \%$ of the shares; banks, conversely, with foreign shareholders control more than 50\% of the stakes will be treated as foreign ownership (Kosak \& Cok, 2008; Mamatzakis et al., 2017).

State ownership should be concerned to discuss the impact of market power on income diversity of a firm. It refers to equity investments by central or local governmental institutions in a firm's equity. They have many different goals than private ownership or foreign ownership that is simplicity for maximizing returns (Mamatzakis et al., 2017). The state ownership can also have two opposite views. In "social" view, state-owned banks can help to overcome market failures, take advantages of externalities, and promote socially desirable welfare enhancing investments (Stiglitz, 1993). In "agency" view, however, it is stressed that even when the government has the best of intentions, the agency costs associated with a government bureaucracy (e.g., the conflict of interests between the government and the bureaucrats designated to manage stated-owned banks) can give a rise to operational inefficiencies and misallocation (Banerjee, 1997; Hart et al., 1997).

\subsection{Empirical Findings}

The prior empirical findings show that the relationship between financial performance and income diversity has been explored already, yet the conclusion is still inconclusive. The diversification in income sources should increase a bank's efficiency, as the results of increasing bank's economies of scale and better performance. Also, income diversity leads to less risk with manageable income. The benefits of diversification, nevertheless, may diminish if there is integration among financial markets (Chiorazzo et al., 2008; Klein \& Saidenberg, 2010).

Particularly, Lee et al., (2014) found that income diversification can give better return in less developed countries due to less integrated financial markets after conducting research in 29 Asia Pacific, Europe, and US banks from 1995 to 2009. They also implied that income diversification brought better resource and competitiveness, and it leaded to better performance.(Gurbuz et al., 2013) In Turkey, income diversity was believed to sturdily increase the risk-adjusted financial performance of deposit banks as well as their stability through doing some new 
activities as brokerage, trading securities and investment banking (Gurbuz et al., 2013). These are also the findings of Meslier et al. (2014) when they investigated in emerging markets. Meanwhile, Chiorazzo et al. (2008) stated that European banks would gained better performance if they diversified their income source onto fee-based activities such as investment banking.

On the other hand, Chiorazzo et al. (2008) also found no significant role of income diversity on bank performance in the US, and it might even harm bank's performance because of its risk exposure. Some researchers alerted giving attention and resources to not-main income generation (or uncertain income generation) might harm the bank's operations, resulting in lower bank's returns, and more important, the market structure of fee-based activities could raise the bank's risks (De Jonghe, 2010; Fiordelisi et al., 2011).

Hitherto, there is so many conflicting results between the relationship between financial performance and income diversity around the world, different stock exchanges or markets will give different results. Moreover, there is still a gap of study how banks' ownership moderates this relationship. Those are motivations for this paper is to be conducted.

\section{Data Sources}

The study is designed to examine the impacts of financial performance and income diversity on stock returns in Vietnam's banking industry. This uses both data of bank-level and country-level. Bank-level data is taken from financial statements (audited and consolidated) and annual reports of Vietnamese commercial banks in a 13-year period from 2007 to 2019, all other types of banks (including one-member limited liability commercial bank owned by the state, $100 \%$ foreign-owned banks, branches of foreign commercial banks, and joint venture banks, ...) are excluded to ensure comparability of results.

Though the author has tried to collect data as many as possible, there are only 26/31 commercial banks have published enough data at least 13-year period of time (listed in Appendix 1). This period is believed to help us investigate all events that have happened as before, during, and aftermath the Global Financial Crisis, especially the M\&A waves in Vietnam (since 2011). For the country-level data, this paper, additionally, use secondary data from the State Bank of Vietnam (SBV), General Statistics Office (GSO), Vietstock.vn, ... so as to meet the study's objectives.

\section{Methodology}

\subsection{Selected Variables}

\subsubsection{Dependent Variables - Financial Performance}

Financial performance of a firm measures how successful the firm is and how it will be utilized as a benchmark for the investors to invest their funds. High performance contributes to an increase in stock market price since investors will respond positively to such signs. The literature on bank performance has focused on the key indicators of profitability as net interest margin (NIM), return on assets (ROA), and return on equity (ROE) (Flamini et al., 2009; Naceur \& Omran, 2011). In this paper, financial performance is proxied by these profitability ratios as well.

ROA is expressed by the net profit as a percentage of total assets. The bank profitability literature suggests ROA as an appropriate measure of the ability of a bank to generate returns on its asset portfolio (Pasiouras \& Kosmidou, 2007; Rivard \& Thomas, 1997), while ROE reflects how effectively a bank management is using its equity capital. Another profitability measure, NIM is the bank's net interest income (interest income minus interest expense) divided by total assets. However, because NIM doesn't reflect profitability, this paper focuses only on ROA and ROE.

\subsubsection{Independent Variables - Income Diversity}

In order to capture the degree of income diversity (IND), the paper uses the ratio of net non-interest income to total operating income (Nguyen M. et al., 2016; Ovi et al., 2014). Net non-interest income includes net profit from services, net gain from trading gold and foreign currencies, net gain from investment and trading securities, net profit from other activities and income from capital contribution/equity investments. Meanwhile, total operating income is the sum of net interest income and net non-interest income (Hidayat et al., 2012; Lepetit et al., 2008).

\subsubsection{Moderating Variable: State Ownership}

In the Vietnamese market, state-owned commercial banks are believed to be the biggest banks (too big to fail) with strong financial resources, wide networks, and various customer base, so they might earn more non-interest income than privately-owned banks (Ho \& Vo, 2019). However, they usually apply lower interests in both loans 
and deposits than the others, so they might mainly focus on traditional activities, being forced to lend to certain sector or industries for supporting their maximizing social welfare objectives, driving to have fewer incentives to innovate banking's services. Thus, the impacts of state ownership are still ambiguous.

In the scope of this study, for the comparison between government-linked banks and non-government-linked banks, we only concern two types of ownership: state and private ownership, excluding other types due to lack of data. Particularly, we focus 3 state-owned commercial banks (in Big 4 banks) and other 24 privately-owned commercial banks. State ownership (OWN) would be treated as a dummy variable.

\subsubsection{Control and Dummy Variables}

Many empirical studies examine the determinants of bank performance. These may be internal or external. The internal determinants are related to bank-specific management decisions as level of liquidity, credit exposure, capital ratio, operational and bank size. The external determinants are industry related, such as reform policies, or regulations, ownership or concentration, and macroeconomic indicators (e.g., CPI inflation, GDP growth, ...). This paper also follows previous established studies by controlling the firm characteristics and macro-factors as well as adding some dummy variables to observe the possible impacts on the dependent variable and eliminate alternative causes or bias findings.

Regarding to the major bank-specific characteristics, the paper uses capital ratio, asset quality, bank size and bank age. Firstly, bank capital plays an important role in determining profitability. Banks with higher capital may need less borrowing and, therefore, the cost of funding is low and they may access cheaper sources of funds (Berger \& Ofek, 1995; Iftekhar et al., 2018). As a result, capital ratio (CAR) is found to have a positive relationship with profitability (Bourke, 1989; Kosmidou, 2008; Molyneux \& Thornton, 1992). The capital ratio indicates the solvency of financial institutions, and it is measured as the total capital divided by total assets.

Secondly, banks are intermediaries between depositors and borrowers. The more deposits are transformed into loans, the higher are net interest income and profits. Therefore, a bank with higher ratio of loans to deposit (LTD) is expect to be more efficient in earning profits because interest income is the major source of bank revenue that impacts the profit positively (Bourke, 1989; Maudos et al., 2002; Rayenda et al., 2018).

The next one is bank size (SIZ), usually measured by the natural log of total assets. Bank size has a significant positive impact on the interest margin (Demirguc-Kunt \& Huizinga, H., 1999). Larger and more profitable banks may have a higher level of technical efficiency. MENA banks was found to have a positive correlation between their size and accounting profitability (Olson \& Zoubi, 2011). However, larger banks may experience poorer performance as a consequence of declining quality of asset portfolio. High-risk loans generate higher accumulation of default loans, and eventually, lower the profitability (Miller \& Noulas, 1997).

Profitability may differ with bank age (AGE) or the number of years of operating. The longer the bank operates, the higher experience, management skills and number of employees, the bigger bank networks through opening more branches, transaction offices, so they might have perform better (Ho \& Vo, 2019).

In term of country-specific variables, it's widely believed that economic growth is good for financial performance. Higher economic growth may strengthen the debt servicing capacity of borrowers, leading to lower the credit risk and higher returns. Therefore, GDP growth rate (GDP) is a variable expected to positively affect the bank's profitability. Another macroeconomic indicator is used in this paper is CPI inflation (CPI). A higher level of inflation may increase bank revenue if income increases more than the cost (Iftekhar et al., 2018; Maudos et al., 2002; Pasiouras \& Kosmidou, 2007).

Moreover, the author also wants to test the impact of listed (LIS), merger and acquisition (MNA), on the bank's financial performance by treating them as dummy variables. In Vietnam, listed banks are usually considered to be the largest and best performing banks, especially those banks which are listed in HOSE and HNX, so it would positively impact on these banks' financial performance. From 2007 to 2019, Vietnam has witnessed many M\&A deals in the banking sector, banks after the merger usually have larger capital, wider network, more customers as well as more bad debts. Consequently, M\&A can cause positive or negative impacts on the banks' performance (Ho \& Vo, 2019). All of these control and dummy variables will be summarized in the Table 1 below.

\subsection{The Research Models and Econometric Methodology}

The panel regression analysis model was employed for the data analysis. Hence, firstly, based on the collected data, the paper will report the descriptive statistics of variables to have a deep understanding of the data set. Next, the author conducts a wide of diagnostics to test correlations among the variables, measuring banks' financial performance and income diversity to clarify correlations among independent variables and other control variables. Then, the appropriate model will be developed and analyzed to reflect the relationship between 
financial performance, income diversity and stock returns for Vietnamese commercial banks.

The study aims to test hypothesis $\mathrm{H}_{1}$ : Income diversity has a positive effect on the bank's financial performance. Also, in order to scrutinize the moderating effects of state ownership in this relationship, the author interacts income diversity with bank ownership dummies to verify the hypothesis $\mathrm{H}_{2}$ : State ownership makes stronger the relationship between income diversity and the bank's financial performance. The specific models used in this research are shown as follows.

$$
\begin{aligned}
& R O A_{i t}=\alpha_{0}+\beta_{1} I N D_{i t}+\beta 2 I N D i t^{*} O W N_{i t}+\beta_{3} C A R_{i t}+\beta_{4} L T D_{i t}+\beta_{5} S I Z_{i t}+\beta_{6} A G E_{i t}+\beta_{7} A G R_{i t}+\beta_{8} G D P_{i t}+ \\
& \beta_{9} I N F_{i t}+\beta_{10} L I S_{i t}+\beta_{l 1} M N A_{i t}+\varepsilon \\
& R O E_{i t}=\alpha_{0}+\beta_{1} I N D_{i t}+\beta 2 I N D i t * O W N_{i t}+\beta_{3} C A R_{i t}+\beta_{4} L T D_{i t}+\beta_{5} S I Z_{i t}+\beta_{6} A G E_{i t}+\beta_{7} A G R_{i t}+ \\
& \beta_{8} G D P_{i t}+\beta_{9} I N F_{i t}+\beta_{10} L I S_{i t}+\beta_{11} M N A_{i t}+\varepsilon
\end{aligned}
$$

\begin{tabular}{|c|c|c|c|c|}
\hline No. & Variables & Symbol & Calculations & Expected sig. \\
\hline \multicolumn{5}{|c|}{ Dependent variable } \\
\hline 1. & Return on assets & ROA & Net profit/Total assets & \\
\hline & Return on equity & ROE & Net profit/Equity & \\
\hline \multicolumn{5}{|c|}{ Independent variable } \\
\hline & Income diversity & IND & Net non-interest income/Total operating income & $+/-$ \\
\hline \multicolumn{5}{|c|}{ Moderating variable } \\
\hline 5. & State ownership & OWN & $\begin{array}{l}\text { 1: State-owned banks } \\
\text { 0: Private-owned banks }\end{array}$ & \\
\hline \multicolumn{5}{|c|}{ Control and dummy variables } \\
\hline \multicolumn{5}{|c|}{ Bank-specific characteristics } \\
\hline 6. & Capital ratio & CAR & Total capital/Total assets & + \\
\hline 7. & Loan-to-deposit & LTD & Loans to customers/Deposit from customers & + \\
\hline 8. & Bank size & SIZ & Ln(total assets) & $+/-$ \\
\hline 9. & Bank age & AGE & $\mathrm{Ln}$ (number of years since establishment) & + \\
\hline \multicolumn{5}{|c|}{ Country-specific variable } \\
\hline 10. & GDP growth rate & GDP & Annual GDP growth rate & + \\
\hline 11. & CPI inflation & INF & Annual CPI inflation & + \\
\hline \multicolumn{5}{|c|}{ Dummy variables } \\
\hline 12. & Listed & LIS & 1: Listed on HOSE or HNX; 0: Otherwise & + \\
\hline 13. & $\mathrm{M} \& \mathrm{~A}$ & MNA & 1: Bank merged; 0: Otherwise & $+/-$ \\
\hline
\end{tabular}

where the subscript $\mathrm{i}$ denotes bank i while $\mathrm{t}$ denotes year $\mathrm{t} ; \alpha, \beta, \varepsilon$ are the intercept, the regression coefficient, and the error term, respectively. All variables are explained in Table 1.

Table 1. Variable definitions

Source: Synthesized by the author.

The framework of this research can be visualized as Figure 2 below.

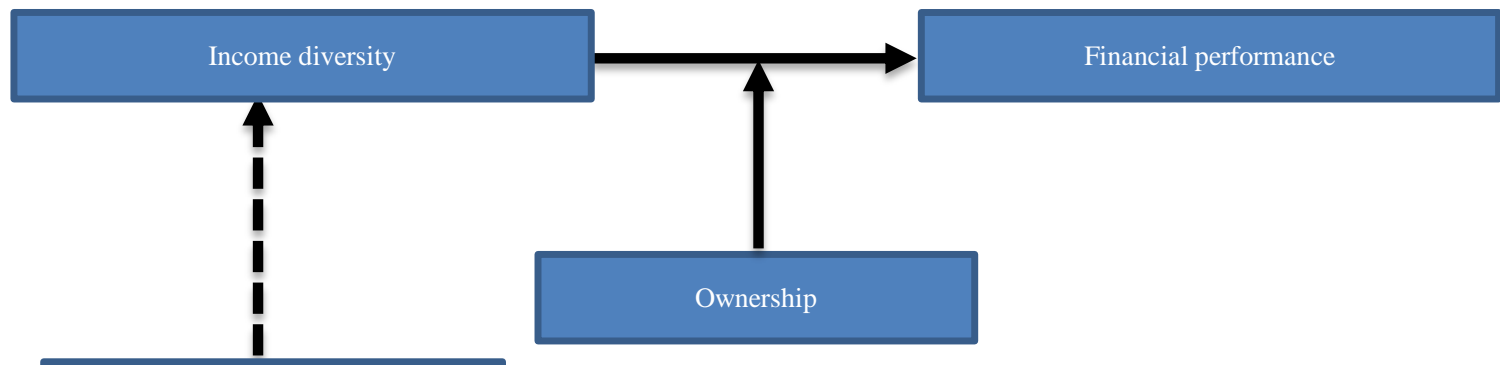

Bank specifics and country

specifics

Figure 2. Research model

Source: Synthesized by the author. 


\section{Empirical Results}

\subsection{Descriptive Statistics}

As mentioned above, this study has the sample of 26 Vietnamese commercial banks over the 13-year period from 2007 to 2019, equivalent to 336 observations (TPB and LPB has data since 2008). Regarding to profitability of the banks, it is not high, or even too low. The mean of ROA and ROE in this period is $0.007(0.7 \%)$ and 0.136 $(13.6 \%)$, respectively. This implies that the banks have not utilized their assets or equity to make profits.

Another main variable is income diversity. It's, unfortunately, also not relatively high when non-interest income makes up around $0.236(23.6 \%)$ on average in total operating income, which indicates that income composition has not been diversified away from the main contribution of interest income from lending activities. The descriptive results of all other variables are presented in Table 2.

Table 2. Descriptive statistics of variables

\begin{tabular}{cccccc}
\hline Variable & Obs & Mean & Std. Dev. & Min & Max \\
\hline ROA & 336 & 0.007269 & 0.001456 & 0.005305 & 0.010268 \\
ROE & 336 & 0.136349 & 0.017462 & 0.096315 & 0.159728 \\
IND & 336 & 0.236312 & 0.64392 & -0.55159 & 11.65027 \\
CAR & 336 & 0.104321 & 0.05941 & 0.029314 & 0.462446 \\
LTD & 336 & 0.892063 & 0.25026 & 0.234964 & 2.514798 \\
SIZ & 336 & 18.13599 & 1.310495 & 14.5267 & 21.12201 \\
AGE & 336 & 2.937992 & 0.597978 & 0 & 4.127134 \\
GDP & 336 & 0.062493 & 0.006451 & 0.05247 & 0.0713 \\
INF & 336 & 7.718547 & 6.214189 & 0.878604 & 23.11632 \\
LIS & 336 & 0.291667 & 0.455208 & 0 & 1 \\
MNA & 336 & 0.113095 & 0.317182 & 0 & 1 \\
OWN & 336 & 0.116071 & 0.320788 & 0 & 1 \\
\hline
\end{tabular}

Source: Resulted from STATA.

\subsection{Correlation Matrix}

The correlation matrix of all variables defined, presented in Table 3, shows that there is insignificant multicollinearity among these variables. The value of correlation among independent, control, and dummy variables in this study is small and less than 0.7 - the correlation level at which researchers often use to examine the possibility of multicollinearity in the research models. To be sure, a VIF test is also conducted, illustrated in Table 4.

Table 3. The correlation matrix

\begin{tabular}{|c|c|c|c|c|c|c|c|c|c|}
\hline & ROA & ROE & NIM & IND & CAR & LTD & SIZ & AGE & GDP \\
\hline ROA & 1 & & & & & & & & \\
\hline ROE & 0.6707 & 1 & & & & & & & \\
\hline NIM & -0.0888 & -0.136 & 1 & & & & & & \\
\hline IND & 0.0399 & -0.007 & -0.2442 & 1 & & & & & \\
\hline CAR & 0.2097 & 0.0423 & 0.366 & -0.0485 & 1 & & & & \\
\hline LTD & 0.0987 & 0.0123 & 0.2223 & -0.0864 & 0.3104 & 1 & & & \\
\hline SIZ & -0.3326 & -0.1213 & -0.0521 & -0.0204 & -0.6942 & -0.2672 & 1 & & \\
\hline AGE & -0.2664 & -0.1034 & -0.0276 & -0.1374 & -0.3857 & 0.0743 & 0.5315 & 1 & \\
\hline GDP & -0.2545 & 0.0417 & -0.063 & 0.0262 & -0.2117 & 0.1573 & 0.203 & 0.1842 & 1 \\
\hline INF & 0.3534 & 0.0106 & 0.0874 & 0.081 & 0.3492 & 0.1183 & -0.3632 & -0.2653 & -0.3862 \\
\hline LIS & -0.1046 & -0.0362 & 0.0446 & -0.034 & -0.2849 & -0.0602 & 0.5453 & 0.3239 & 0.0484 \\
\hline MNA & -0.2261 & -0.0417 & -0.2277 & 0.0278 & -0.214 & -0.1167 & 0.3464 & 0.2287 & 0.1467 \\
\hline \multirow[t]{2}{*}{ OWN } & 0.0003 & -0.001 & -0.0059 & -0.0044 & -0.2521 & 0.0877 & 0.5427 & 0.4705 & 0.0029 \\
\hline & INF & LIS & MNA & OWN & & & & & \\
\hline INF & 1 & & & & & & & & \\
\hline LIS & -0.1438 & 1 & & & & & & & \\
\hline MNA & -0.2383 & 0.143 & 1 & & & & & & \\
\hline OWN & 0.0002 & 0.3399 & 0.0173 & 1 & & & & & \\
\hline
\end{tabular}

Source: Resulted from STATA. 
Table 4. VIF test of Model 1 and 2

\begin{tabular}{lcccc}
\hline Variable & VIF & 1/VIF & Variable & VIF \\
\hline Model 1 & & & Model 2 & \\
SIZ & 4.01 & 0.249196 & SIZ & 0.249196 \\
CAR & 2.19 & 0.4563 & CAR & 0.01 \\
INDxOWN & 1.76 & 0.568425 & INDxOWN & 0.19 \\
AGE & 1.72 & 0.580261 & AGE & 1.76 \\
LIS & 1.49 & 0.671401 & LIS & 1.72 \\
INF & 1.41 & 0.707916 & INF & 1.49 \\
LTD & 1.33 & 0.749492 & LTD & 0.580261 \\
GDP & 1.3 & 0.768536 & GDP & 0.707916 \\
MNA & 1.23 & 0.809991 & MNA & 1.33 \\
IND & 1.06 & 0.942857 & IND & 0.749492 \\
Mean VIF & $\mathbf{1 . 7 5}$ & & Mean VIF & 0.768536 \\
\hline
\end{tabular}

Source: Resulted from STATA.

\subsection{Regression Results}

The regression results start with Pooled OLS, FEM and REM, showed in Table 5 and 6. To test the assumptions and appropriateness of these models, the author also performed a wide of diagnostics as White's test/Modified Wald/Breusch and Pagan test for heteroskedasticity, Wooldridge test for autocorrelation, and Hausman test for FEM or REM specification. In the two models, they both have heteroskedasticity and autocorrelation problems, which can make the results of the research models not certain and false. Therefore, the selection of Pooled OLS are almost no significance.

The author also tried to use FEM and REM, which appropriate for model 1 and 2, respectively (based on the Hausman test), but they still don't fix the autocorrelation. As Wooldridge, (2002), General Least Square (GLS) could be used to overcome these problems. This method was used and presented in Table 5 and 6as well.

Table 5. Regression results of model 1

\begin{tabular}{|c|c|c|c|c|}
\hline Variables & Pooled OLS & FEM & REM & GLS \\
\hline IND & $\begin{array}{c}-0.0000184 \\
(-0.16)\end{array}$ & $\begin{array}{c}-0.0000501 \\
(-0.46)\end{array}$ & $\begin{array}{c}-0.0000184 \\
(-0.16)\end{array}$ & $\begin{array}{c}-0.0000293 \\
(-0.31)\end{array}$ \\
\hline INDxOWN & $\begin{array}{c}0.00477 * * * \\
(3.92)\end{array}$ & $\begin{array}{c}-0.0000815 \\
(-0.02)\end{array}$ & $\begin{array}{c}0.00477 * * * \\
(3.92)\end{array}$ & $\begin{array}{c}-0.000311 \\
(-0.08)\end{array}$ \\
\hline CAR & $\begin{array}{c}-0.00432 * * \\
(-2.48)\end{array}$ & $\begin{array}{c}-0.00661 * * * \\
(-3.36)\end{array}$ & $\begin{array}{c}-0.00432 * * \\
(-2.48)\end{array}$ & $\begin{array}{c}-0.00589 * * * * \\
(-3.05)\end{array}$ \\
\hline LTD & $\begin{array}{c}0.000223 \\
(0.69)\end{array}$ & $\begin{array}{c}0.000351 \\
(0.94)\end{array}$ & $\begin{array}{c}0.000223 \\
(0.69)\end{array}$ & $\begin{array}{c}0.000134 \\
(0.37)\end{array}$ \\
\hline SIZE & $\begin{array}{c}-0.000482 * * * \\
(-4.50)\end{array}$ & $\begin{array}{c}-0.000664 * * * \\
(-3.31)\end{array}$ & $\begin{array}{c}-0.000482 * * * \\
(-4.50)\end{array}$ & $\begin{array}{c}-0.000509^{* * *} \\
(-2.42)\end{array}$ \\
\hline AGE & $\begin{array}{c}-0.000461 * * * \\
(-3.00)\end{array}$ & $\begin{array}{c}-0.00190 * * * \\
(-4.51)\end{array}$ & $\begin{array}{c}-0.000461 * * * \\
(-3.00)\end{array}$ & $\begin{array}{c}-0.00208 * * * * \\
(-4.59)\end{array}$ \\
\hline GDP & $\begin{array}{c}-0.0254 * * \\
(-2.05)\end{array}$ & $\begin{array}{l}-0.0157 \\
(-1.31)\end{array}$ & $\begin{array}{c}-0.0254^{* *} \\
(-2.05)\end{array}$ & $\begin{array}{c}0.00429 \\
(0.39)\end{array}$ \\
\hline INF & $\begin{array}{c}0.0000403 * * * \\
(3.01)\end{array}$ & $\begin{array}{c}-0.00000832 \\
(-0.58)\end{array}$ & $\begin{array}{c}0.0000403 * * * \\
(3.01)\end{array}$ & $\begin{array}{c}-0.00000718 \\
(-0.59)\end{array}$ \\
\hline LIS & $\begin{array}{c}0.000331^{*} \\
(1.76)\end{array}$ & $\begin{array}{c}0.0000139 \\
(0.04)\end{array}$ & $\begin{array}{c}0.000331^{*} \\
(1.76)\end{array}$ & $\begin{array}{c}0.0000727 \\
(0.20)\end{array}$ \\
\hline MNA & $\begin{array}{c}-0.000122 \\
(-0.50)\end{array}$ & $\begin{array}{c}-0.000497 \\
(-1.50)\end{array}$ & $\begin{array}{c}-0.000122 \\
(-0.50)\end{array}$ & $\begin{array}{c}-0.000686^{*} \\
(-1.92)\end{array}$ \\
\hline _cons & $\begin{array}{c}0.0187 * * * \\
(8.72)\end{array}$ & $\begin{array}{c}0.0264 * * * \\
(8.39) \\
\end{array}$ & $\begin{array}{c}0.0187 * * * \\
(8,72)\end{array}$ & $\begin{array}{c}0.0228 * * * \\
(7.16)\end{array}$ \\
\hline No. of obs. & 336 & 336 & 336 & 336 \\
\hline No. of groups & & 26 & 26 & 26 \\
\hline Prob $>$ F/ Prob $>$ chi 2 & 0.0000 & 0.0000 & 0.0000 & 0.0000 \\
\hline R-squared & 0.248 & 0.3865 & 0.3181 & \\
\hline White's test & Prob $>$ chi $2=0.0000$ & & & \\
\hline Wooldridge test & \multirow{2}{*}{\multicolumn{4}{|c|}{$\begin{aligned} & \text { Prob }>F=0.0000 \\
& \text { Prob }>\text { chi } 2=0.0000 \\
& \text { Prob }>\text { chi } 2= 1.0000\end{aligned}$}} \\
\hline $\begin{array}{l}\text { Hausman test } \\
\text { Modified Wald test } \\
\text { Breusch \& Pagan test }\end{array}$ & & & & \\
\hline
\end{tabular}

Source: Resulted from STATA. $t$ statistics in brackets. $* \mathrm{p}<0.1, * * \mathrm{p}<0.05, * * * \mathrm{p}<0.01$. 
Table 6. Regression results of model 2

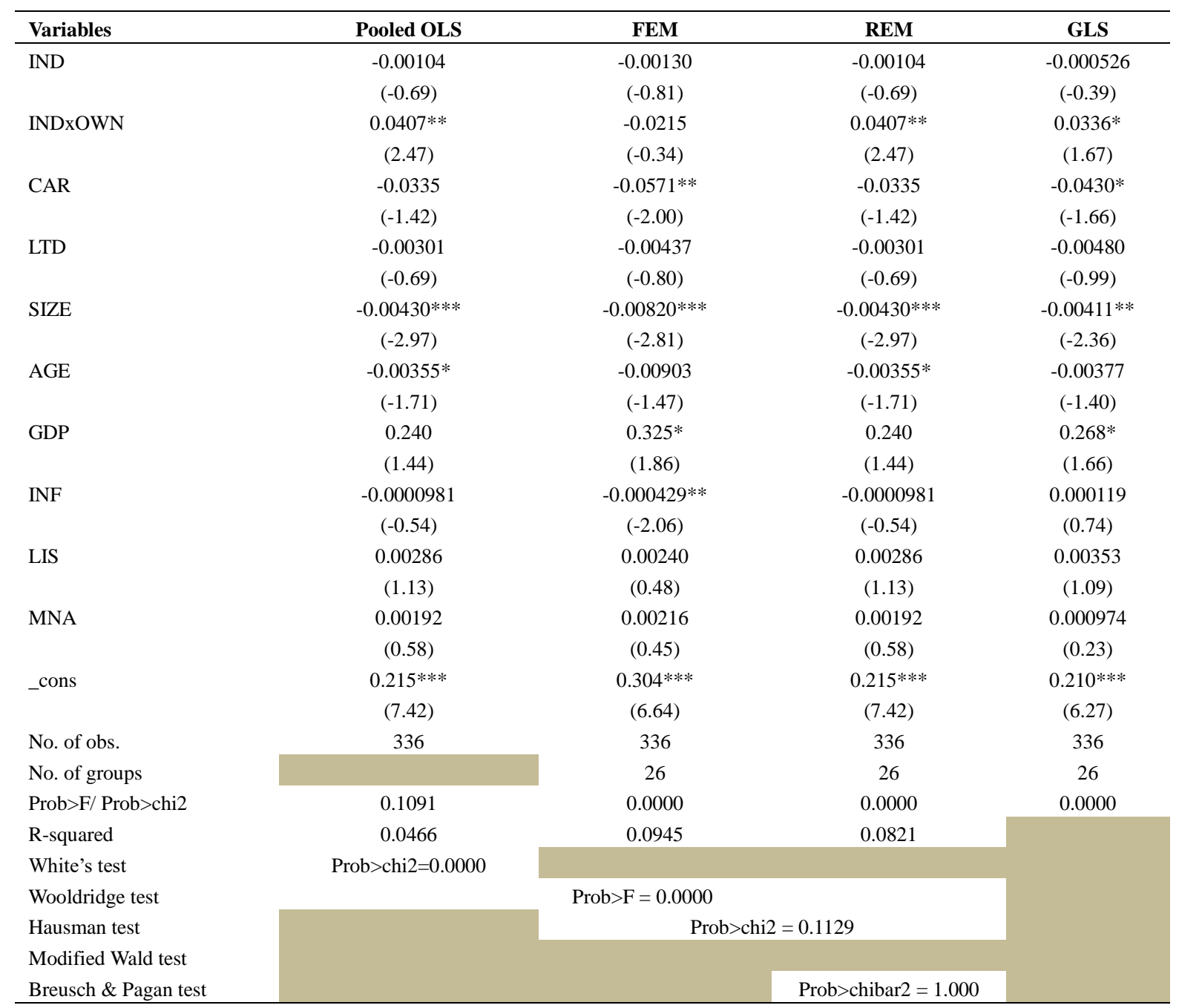

Note. $\mathrm{t}$ statistics in brackets. $* \mathrm{p}<0.1, * * \mathrm{p}<0.05, * * * \mathrm{p}<0.01$.

Source: Resulted from STATA.

The regression results in the both models, unfortunately, show that there is no relationship between financial performance and income diversity, so we reject $\mathrm{H}_{1}$ : Income diversity has a positive effect on the bank's financial performance. However, the model 2 also reveals a strong evidence to support hypothesis 2 that state ownership strengthens the relationship between financial performance and income diversity when the interaction variable (INDxOWN) are positive and statistically significant at 0.1 level. This implies that state-owned banks, fascinatingly, with the advantages of the relatively bigger size, scope, financial sources, and customer base, could diversify their income into non-traditional activities more easily than their privately-owned counterparts; and therefore, they perform better.

Regarding to bank-specific variables, the results are found the same through 2 models. In general, they show a negative and significant coefficient for CAR and SIZ. This is contrary to the findings of Bourke (1989), Kosmidou (2008), and Molyneux and Thornton (1992), but it's in the line with the studies of Miller and Noulas (1997). Both of the two variables had a relatively small impact on the banks' performance.

There are also some differences between the two models. In the model 1, AGE and MNA have a negative relationship with ROA, indicating that the larger and older banks perform less efficiently and merged banks might also suffer from bad debts. These findings are completely opposite to the findings of Ho \& Vo (2019).

In the model 2, GPD, obviously, are found to have a positive impact on financial performance of the banks. This result is the same as most recent studies. The other variables have no significant coefficients. 


\section{Conclusions and Suggestions}

The paper was conducted to ascertain the relationship between financial performance and income diversity and whether state ownership moderates this relationship or not in the context of diversifying banks' income structure become a trend worldwide in the past 3 decades, which is also encouraged by the Governor and the SBV recently. The research problems were explored by using the data of 26 Vietnamese joint stock commercial banks from 2007 to 2019 to ensure the results are up-to-date and could be capture precisely.

As usual, the research models were analyzed through the most common methods for panel data as Pooled OLS, FEM, REM and GLS. However, the first 3 traditional methods resulted in phenomena of autocorrelation, which made the regression results no more reliable. In order to overcome this problem, the study employed the GLS method.

The research findings indicate that income diversity has no impact on financial performance because the Vietnamese commercial banks are still focusing on lending activities or relying on the interest income too much, which makes up over 70 percent in total operating income. The finding contributes the current literature when Vietnamese banking industry are diversifying its income from traditional activities into non-traditional activities steadily. Maybe, in the following years, the impacts of income diversity on financial performance could be clearer and easier to capture than the current status.

The findings may be helpful for investors, bank managers and policy makers for their own purposes. Firstly, investors should consider the higher income diversity banks when buying stock in the near future when the income from non-lending activities becomes the main part in the total operating income. For bank managers, they should reduce the relying on interest income, change the income structure followed the guides of the SBV. Moreover, they need to control the costs when diversifying their income, especially general and administrative costs, as well as use their capital effectively in order to invest in-depth advanced technologies, helping reduce operating costs or develop more non-traditional products and services to serve more customers and earn more non-interest income. The fees come from non-traditional activities may be cheap for individuals, but it can become a huge profit when accumulating the whole customer base in each bank. Markedly, bank managers in private ownership must have particular solutions to close the gap with their state-owned counterparts in diversifying the income structure.

For policy makers, in the period of market recovering, they should have some encouragements to boost the commercial banks diversifying their business lines instead of focusing on traditional activities, which might lead to credit overheating growth and can "boom" anytime and credit activities are vulnerable to unexpected events. This is really necessary under the context of severely impacts of the COVID-19 on the financial system, illustrated by the increase of bad debts. As of the beginning of March 2020, there are 23 credit institutions that have reported the impact of the pandemic. According to which, an estimated VND 926 trillion of outstanding loans were being affected by the COVID-19, accounting for $14.27 \%$ of total loans of these 23 credit institutions and $11.3 \%$ of total loans of the whole financial system. By mid-April 2020, the figure increased to about VND 2,000 trillion, making up $23 \%$ of the total outstanding loans. In addition to bringing many benefits to banks and helping banks to overcome the non-performing loans, diversification in banking activities also brings great benefits to customers for both individuals/businesses and even the country's economy. The increase of non-traditional activities as import and export financing, factoring, collections, etc., has boosted production growth, thereby, the Vietnam economy would be able to stabilize and develop. Additionally, the State needs to reduce their involvement in banking operations (by fully equitization from state-owned joint stock commercial banks as BIDV, Vietinbank and Vietcombank) to create a fair competition market for domestic banking sector. The last but not least, policy makers might need to pay attention to service fees given by the banks when really necessary (especially when the banking sector in Vietnam is not a perfect competition market, which cannot use the invisible hand of supply and demand) to protect customers' interests because some large banks tend to charge high fees from non-traditional activities. For instance, Vietcombank, Vietinbank, BIDV, MBBank is typical examples when they charge highly fees from transferring money interbank, from VND 6,600 to 11,000 per transaction; withdrawing money from ATM, approximately VDN 1,100 per transaction; and SMS banking of these banks fluctuates from VND 8,800 to 11,000 per month.

\section{References}

Anwaar, M. (2016). Impact of firms' performance on stock returns - Evidence from listed companies of FTSE-100 Index, London, UK. Global Journal of Management and Business Research, 16(1), 30-39.

Banerjee, A. V. (1997). A theory of misgovernance. The Quaterly Journal of Economics, 112(4), 1289-1332. 
Barry, T. A., Lepetit, L., \& Tarazi, A. (2011). Ownership structure and risk in publicly held and privately owned banks. Journal of Banking and Finance, 35(5), 1327-1340. https://doi.org/10.1016/j.jbankfin.2010.10.004

Berger, P. G., \& Ofek, E. (1995). Diversification's effect on firm value. Journal of Financial Economics, 37(1), 39-65. https://doi.org/10.1016/0304-405X(94)00798-6

Bourke, P. (1989). Concentration and other determinants of bank profitability in Europe, North America and Australia. Journal of Banking and Finance, 13, 65-79. https://doi.org/10.1016/0378-4266(89)90020-4

Chiorazzo, V., Milani, C., \& Salvini, F. (2008). Income diversification and bank performance: Evidence from Italian banks. Journal of Financial Services Research, 33(3), 181-203. DOI: 10.1007/s10693-008-0029-4

De Jonghe, O. (2010). Back to the basics in banking? A micro-analysis of banking system stability. Journal of Financial Intermediation, 19(3), 387-417.

Demirguc-Kunt, A., \& Huizinga, H. (1999). Determinants of commercial bank interest margins and profitability: Some international evidence. World Bank Review, 13, 379-408. https://doi.org/10.1596/1813-9450-1900

DeYoung, R., \& Roland, K. (2001). Product mix and earnings volatility at commercial banks: Evidence from a degree of total leverage model. Journal of Financial Intermediation, 10, 54-84. DOI:10.1006/jfin.2000.0305

Fauver, L., Houston, J., \& Naranjo, A. (2003). Capital market development, international integration, legal systems, and the value of corporate diversification: A cross-country analysis. Journal of Financial and Quantitative Analysis, 38(1), 135-158.

Felicia, O., \& Akin, I. (2018). Bank's financial performance and stock returns in Nigeria. International Journal of Research in Business, Economics and Management, 2(4).

Fiordelisi, F., Marques-Ibanez, D., \& Molyneux, P. (2011). Efficiency and risk in European banking. Journal of Banking and Finance, 35(5), 1315-1326. https://doi.org/10.1016/j.jbankfin.2010.10.005

Flamini, V., Mcdonald, C., \& Schumacher, L. (2009). The determinants of commercial bank profitability in Sub-Saharan Africa. IMF Working Paper.

Gatua, F. K. (2013). Analysis of share price determinants at Nairobi securities exchange. University of Nairobi.

Gorton, G., \& Rosen, R. (1995). Corporate Control, portfolio choice, and the decline in banking. Journal of Finance, 50, 1377-1419.

Gurbuz, A. O., Yanik, S., \& Ayturk, Y. (2013). Income diversification and bank performance: Evidence from Turkish banking sector. Journal of BRSA Banking and Financial Markets, 7(1), 9-29.

Hafidiyah, M., \& Trinugroho, I. (2016). Revenue Diversification, Performance and Bank Risk: Evidence from Indonesia. Jurnal Dinamika Manajemen, 7(2), 139-148.

Hart, O. D., Shleifer, A., \& Vishny, R. (1997). The proper scope of government: Theory and application to prisons. Quarterly Journal of Economics, 112, 1127-1162.

Ho, T., \& Vo, Q. (2019). The relationship between market power and income diversity with ownership structure as a moderator-A study of Vietnamese commercial banks. Asian Journal of Economics, Business and Accounting, 10(3), 1-16. https://doi.org/10.9734/ajeba/2019/v10i330106

Iftekhar, R., Ruhul, S., \& Harry, B. (2018). Financial performance of commercial banks in the post-reform era: Further evidence from Bangladesh. Economic Analysis and Policy, 58, 43-54. https://doi.org/10.1016/j.eap.2018.01.001

Jesen, M. C., \& Meckling, E. H. (1976). Theory of firm: Managerial behavior, agency costs and ownership structure. Journal of Financial Economics, 3, 305-360. https://doi.org/10.1016/0304-405X(76)90026-X

Juniarta, I. W., \& Purbawangsa, I. B. A. (2020). The effect of financial performance on stock return at manufacturing company of Indonesia stock exchange. Russian Journal of Agricultural and Social-Economic Sciences, 1(97). DOI: 10.18551/rjoas.2020-01.02

Klein, P. G., \& Saidenberg, M. R. (2010). Organizational structure and the diversification discount: Evidence from commercial banking. The Journal of Industrial Economics, 58(1), 127-155. http://dx.doi.org/10.1111/j.1467-6451.2010.00409.x

Kosak, M., \& Cok, M. (2008). Ownership structure and profitability of the banking sector: The evidence from the SEE region. Preliminary Communication UDC, 26(1), 93-122. 
Kosmidou, K. (2008). The determinants of banks' profits in Greece during the period of EU financial integration. Managerial Finance, 34, 146-159. https://doi.org/10.1108/03074350810848036

Lassoued, N., Sassi, H., \& Attia, M. B. R. (2016). The impact of State and Foreign ownership on banking risk: Evidence from the MENA countries. Research in International Business and Finance, 36, 167-178. https://doi.org/10.1016/j.ribaf.2015.09.014

Lee, C. C., Hsieh, M. F., \& Yang, S. J. (2014). The relationship between revenue diversification and bank performance: Do financial structures and financial reforms matter? Japan and the World Economy, 29, 18-35. https://doi.org/10.1016/j.japwor.2013.11.002

Lu, J. W., \& Beamish, P. W. (2004). International diversification and firm performance: The S-curve hypothesis. Academy of Management Journal, 47(4), 598-609.

Mamatzakis, E., Zhang, X., \& Wang, C. (2017). Ownership structure and bank performance: An emerging market perspective. Munich Personal RePEc Archive.

Maudos, J., Pastor, J. M., Perez, F., \& Quesada, J. (2002). Cost and profit efficiency in European banks. Journal of International Financial Market, Institution \& Money, 12, 33-58. https://doi.org/10.1016/S1042-4431(01)00051-8

Mc Gregor, R., \& Mc Gregor, A. (1989). The mechanics of the Johannesburg stock exchange. Juta and Company Limited, Cape Town.

Meslier, C., Tacneng, R., \& Taraxi, A. (2014). Is bank income diversification beneficial? Evidence from an emerging economy. Journal of International Financial Market, Institution \& Money, 31, 97-126. https://doi.org/10.1016/j.intfin.2014.03.007

Miller, S. M., \& Noulas, A. G. (1997). Portfolio mix and large-bank profitability in the USA. Applied Economics, 29, 505-512. https://doi.org/10.1080/000368497326994

Mishkin, F. S., \& Eakins, S. G. (2010). Financial markets and institutions (7th ed.). Pearson.

Molyneux, P., \& Thornton, J. (1992). Determinants of European bank profitability: A note. Journal of Banking and Finance, 16, 1173-1178. https://doi.org/10.1016/0378-4266(92)90065-8

Myers, S. C. (2001). Capital structure. The Journal of Economic Perspectives, 15(2), 81-102.

Naceur, S. B., \& Omran, M. (2011). The effects of bank regulations, competition, and financial reforms on banks' performance. Emerging Markets Review, 12, 1-20. https://doi.org/10.1016/j.ememar.2010.08.002

Ngo, G., \& Dang, T. (2016). Financial performance, dividend payment and firm value - An exploratory research on Vietnam listed firms in the food and drink industry. VNU Journal of Science: Economics and Business, 32(2), 47-57.

Olson, D., \& Zoubi, T. (2011). Efficiency and bank profitability in MENA countries. Emerging Markets Review, 12, 94-110. https://doi.org/10.1016/j.ememar.2011.02.003

Pasiouras, F., \& Kosmidou, K. (2007). Factors influencing the profitability of domestic and foreign commercial banks in the European Union. Research in International Business and Finance, 21, 222-237. https://doi.org/10.1016/j.ribaf.2006.03.007

Rayenda, B., Maria, K., \& Rachel, E. G. (2018). Income diversification and bank performance: Evidence from Malaysian banks. Economics Bulletin, 38(2), 799-809.

Rivard, R. J., \& Thomas, C. R. (1997). The effect of interstate banking on large bank holding company $\begin{array}{llll}\text { profitability and risk. Journal Economics Business, 49, 61-76. } & \text {. }\end{array}$ https://doi.org/10.1016/S0148-6195(96)00041-0

Rogers, K., \& Sinkey, J. F. (1999). An analysis of non-traditional activities at U.S. commercial banks. Review of Financial Economics, 8(1), 25-39.

Stiglitz, J. E. (1993). The role of the state in financial markets. The World Bank Economic Review, 7(1), 19-52.

Wooldridge, J. (2002). Introductory Econometrics: A Modern Approach. South-Western College.

Zahavi, T., \& Lavie, D. (2013). Intra-industry diversification and firm performance. Strategic Management Journal, 34(8), 978-998. https://doi.org/10.1002/smj.2057 


\section{Appendix A}

List of Vietnamese commercial banks used in this study

\begin{tabular}{|c|c|c|c|c|c|c|c|}
\hline No. & Name & ID & S.E. & No. & Name & ID & S.E. \\
\hline 1 & $\begin{array}{l}\text { JSC Bank for Investment \& Development } \\
\text { of Vietnam }\end{array}$ & BID & HoSE & 14 & Kien Long JSC Bank & KLB & UPCoM \\
\hline 2 & Vietnam JSC Bank for Industry \& Trade & CTG & HoSE & 15 & LienViet Post JSC Bank & LPB & UPCom \\
\hline 3 & JSC Bank for Foreign Trade of Vietnam & VCB & HoSE & 16 & VN International JSC Bank & VIB & UPCom \\
\hline 4 & Vietnam JSC Export Import Bank & EIB & HoSE & 17 & AnBinh JSC Bank & ABBank & OTC \\
\hline 5 & Ho Chi Minh Development JSC Bank & HDB & HoSE & 18 & VN Maritime JSC Bank & MSB & OTC \\
\hline 6 & Military JSC Bank & MBB & HoSE & 19 & Nam A JSC Bank & NamABank & OTC \\
\hline 7 & Sai Gon Thuong Tin JSC Bank & STB & HoSE & 20 & Orient JSC Bank & OCB & OTC \\
\hline 8 & VN Technological \& Commercial JS Bank & TCB & HoSE & 21 & Petrolimex Group JSC Bank & PGBank & OTC \\
\hline 9 & Tien Phong JSC Bank & $\mathrm{TPB}$ & HoSE & 22 & Saigon JSC Bank & $\mathrm{SCB}$ & OTC \\
\hline 10 & VN Prosperity JSC Bank & VPB & HoSE & 23 & Southeast Asia JSC Bank & SeABank & OTC \\
\hline 11 & Asia JSC Bank & $\mathrm{ACB}$ & HoSE & 24 & Saigon JSC Bank for Industry \& Trade & SGB & OTC \\
\hline 12 & National Citizen JSC Bank & NVB & HNX & 25 & VN Asia JSC Bank & VietABank & OTC \\
\hline 13 & Saigon Hanoi JSC Bank & SHB & HNX & 26 & Viet Capital JSC Bank & VietCapital & OTC \\
\hline \multicolumn{8}{|c|}{ Excluding } \\
\hline No. & Name - ID & S.E. & \multicolumn{3}{|c|}{ Reasons of excluding } & & \\
\hline 27 & Bao Viet JSC Bank - BaoVietBank & OTC & \multicolumn{3}{|c|}{$\begin{array}{l}\text { It's relatively a new player in } \mathrm{Vi} \\
\text { since } 2009\end{array}$} & sector, publis & ling data \\
\hline 28 & Vietnam Public JSC Bank - PVcomBank & OTC & \multicolumn{3}{|c|}{$\begin{array}{l}\text { It's resulted from the M\&A deal between Weste } \\
\text { Finance Company, publishing data since } 2013\end{array}$} & 3ank and Petro & Vietnam \\
\hline 29 & Bac A JSC Bank - BAB & UPCoM & \multicolumn{3}{|c|}{ It has only published data since 2012} & & \\
\hline 30 & Vietnam Thuong Tin JSC Bank - Vietbank & OTC & \multicolumn{3}{|c|}{ It's a new player, publishing data since 2016} & & \\
\hline 31 & Dong A JSC Bank - DongABank & OTC & \multicolumn{5}{|c|}{ It is under special control by the SBV and not publishing data since 2014} \\
\hline
\end{tabular}

\section{Copyrights}

Copyright for this article is retained by the author(s), with first publication rights granted to the journal.

This is an open-access article distributed under the terms and conditions of the Creative Commons Attribution license (http://creativecommons.org/licenses/by/4.0/). 